Araştırma Makalesi/Research Article

\title{
Determination of Biological Properties of Plutella xylostella (Linnaeus, 1758) (Lepidoptera: Plutellidae)
}

\author{
Ceren Saran (iD Hanife Genç* iD
}

Çanakkale Onsekiz Mart University, Faculty of Agriculture, Department of Agricultural Biotechnology, 17100, Çanakkale, Turkey.

*Corresponding author: hgenc@comu.edu.tr

Geliş Tarihi: 18.03.2021

Kabul Tarihi: 04.05.2021

\begin{abstract}
Plutella xylostella (Linnaeus, 1758), the diamondback moth is an important pest in Brassicae cultivars in the world. However, description regarding different biological stages and information about performance parameters of $P$. xylostella are important to survey in fields and design an effective management. In this study, wild population of diamondback moth was adapted on white cabbage then cauliflower, broccoli and white cabbage leaves were tested under laboratory conditions at $20 \pm 2^{\circ} \mathrm{C}, 50 \%$ relative humidity and $16: 8$ (L:D) photoperiod. The development times were $23.41 \pm 0.38$ days on white cabbage, $25.12 \pm 0.56$ days on cauliflower and $26.05 \pm 0.56$ days on broccoli leaves. The generation times were $25.03 \pm 0.42$ days on cauliflower, $29.99 \pm 1.49$ days on broccoli and $30.47 \pm 1.04$ days on white cabbage leaves. The eggs were laid individually or in the shape of small groups on the host leaves. There were 4 instars based on molting and head capsule diameters of all tested hosts. In this study, durations of larval stages, the number of laid eggs, larval sex differentiation and fitness parameters of the diamondback moth were determined on cauliflower, broccoli and white cabbage host plants.
\end{abstract}

Keywords: Plutella xylostella, diamondback moth, cauliflower, laboratory rearing

\section{Plutella xylostella (Linnaeus, 1758) (Lepidoptera: Plutellidae)'nın Biyolojik Özelliklerinin Belirlenmesi $\ddot{O} \mathbf{z}$}

Plutella xylostella (Linnaeus, 1758), elmas sırtlı güve, dünyadaki Brassicae çeşitlerindeki önemli bir zararlıdır. Bununla birlikte, farklı biyolojik dönemleri ile ilgili açıklamalar ve $P$. xylostella'nın performans parametreleri hakkındaki bilgiler, tarlalarda sörvey yapmak ve etkili bir mücadele tasarlamak için önemlidir. Bu çalışmada, yabani $P$. xylostella popülasyonu beyaz lahana üzerinde adapte edildikten sonra karnabahar, brokoli ve beyaz lahana yapraklarında $20 \pm 2{ }^{\circ} \mathrm{C}, \% 50$ bağıl nem ve 16: 8 (L: D) fotoperiyottaki laboratuvar koşullarında test edilmiştir. Gelişme süresi, karnabaharda $23.41 \pm 0.38$ gün, brokoli üzerinde $25.12 \pm 0.56$ gün ve beyaz lahana yapraklarında 26.05 \pm 0.56 gündür. Generasyon süresi, karnabaharda $25.03 \pm 0.42$ gün, brokoli üzerinde $29.99 \pm 1.49$ gün ve beyaz lahana yapraklarında $30.47 \pm 1.04$ gündür. Yumurtalar tek tek veya küçük gruplar halinde konukçu yaprakların üzerine bırakılmıştır. Test edilen tüm konukçulardaki larvalarda deri değiştirme ve kafa kapsül ölçümlerine bağlı olarak 4 larva dönemi belirlendi. Bu çalışmada, elmas sırtlı güvesinin karnabahar, brokoli ve beyaz lahanada üzerinde larva dönemlerinin gelişme süreleri, bırakılan yumurta sayısı, larva cinsiyet farklılaşması ve performans parameterleri belirlenmiştir.

Anahtar kelimeler: Plutella xylostella, elmas sirtlı güve, karnabahar, laboratuvarda yetiştirme

\section{Introduction}

Cabbage leaf moth or commonly known as the diamondback moth, Plutella xylostella (Linnaeus, 1758) (Lepidoptera: Plutellidae) is a crucial pest of cruciferous plants (Talekar and Shelton, 1993). It is probably originated in Europe, now distributed Southeast Asia, South Africa, Australia, New Zealand and throughout the America (Kfir, 1998; De Bartoli et al., 2014). Diamondback moth attacks all cruciferous crops, including broccoli (Brassica oleracea var. italica), Brussels sprouts (Brassica oleracea var. gemmifera), cabbage (Brassica oleracea var. capitata), Chinese cabbage (Brassica rapa subsp. pekinensis), cauliflower (Brassica oleracea var. botrytis), collard (Brassica oleracea var. viridis), kale (Brassica oleracea var. sabellica), kohlrabi (Brassica oleracea Gongylodes Group), mustard (Brassica juncea), radish (Raphanus sativus var. longipinnatus), turnip (Brassica 
rapa subsp. rapa), and watercress (Nasturtium officinale) and several cruciferous weeds. Host plants are not equally preferred, for example, collard is chosen for egg laying relative to cabbage (Talekar and Shelton, 1993). In Turkey, diamondback moth was initially reported in Artvin, Murgul district in 1965 (Alkan, 1965) then had spread to Erzurum (Avc1 and Özbek, 1990) and recently observed in Çanakkale (Atay et al., 2019).

The diamondback moth is an invasive pest and easily adapt to different climate conditions with high fecundity (Talekar et al., 1985, Avc1 and Özbek, 1990). It has been reported that it migrates to $1000 \mathrm{~km}$ or longer distances with the air flow caused by atmospheric pressure in Europe (French and White, 1960; Avc1 and Özbek, 1990). The diamondback moth has been reported as the most serious pest of cruciferous crops in the world, causing crop losses of more than $90 \%$ and the managing cost was about US\$ 4 billion annually (Zalucki et al., 2012). Because of the frequent applications of insecticides, it has known to be resistant to synthetic insecticides and Bacillus thuringiensis in Asia (Mohan and Gujar, 2003), Hawaii (Tabashnik et al., 1990), North and Central America (Magaro and Edelson, 1990).

The life table parameters of a pest are crucial to understand its population dynamics, control methods and adaptations to the new environment. Even though, many studies have conducted to investigate the biology of $P$. xylostella on different hosts (Colinet et al., 2015; Saeed et al., 2019) but those investigations are lacking in Turkey. Additionally, pest population changes in different ecological areas based on the distribution of host ranges and other ecological factors. These differences demand to study the pest's biology, preferred host plants and adaptations under laboratory conditions. In the presented study, the life span of P. xylostella was studied on white cabbage, cauliflower and broccoli in the controlled conditions.

\section{Material and Methods \\ Tested host plant}

The leaves of cabbage (Brassica oleracea var. capitata), cauliflower (Brassica oleracea var. botrytis) and broccoli (Brassica oleracea var. italica) were harvested as necessary in a local field and used to rear the immature stages of $P$. xylostella under favorable laboratory conditions.

\section{Insect rearing}

Different biological stages of diamondback moth were collected and brought to laboratory from local Brassicae fields in Çanakkale province in October and November 2019. Field damages of diamondback moth in Brassicae field were observed (Figure 1A, B, C). Host leaves were wrapped with moistened cotton then placed in Tupperware containers with a towel paper at the bottom (Figure 2A). Collected larvae from the fields were reared to pupal stage and pupae were harvested with soft-tipped forceps then transferred into a petri dish. The adult cages with white chiffon cloth $(45 \times 45 \times 45 \mathrm{~cm})$ were established having host plant leaves and a piece of cotton soaked with $10 \%$ honey solution (Figure 2B). The diamondback moth colony was maintained 3-4 generations continuously on cabbage leaves before setting up the experiments. All experiments were conducted under controlled conditions at $20 \pm 2^{\circ} \mathrm{C}, 50 \% \mathrm{RH}$ and 16: 8 (L:D) photoperiods.
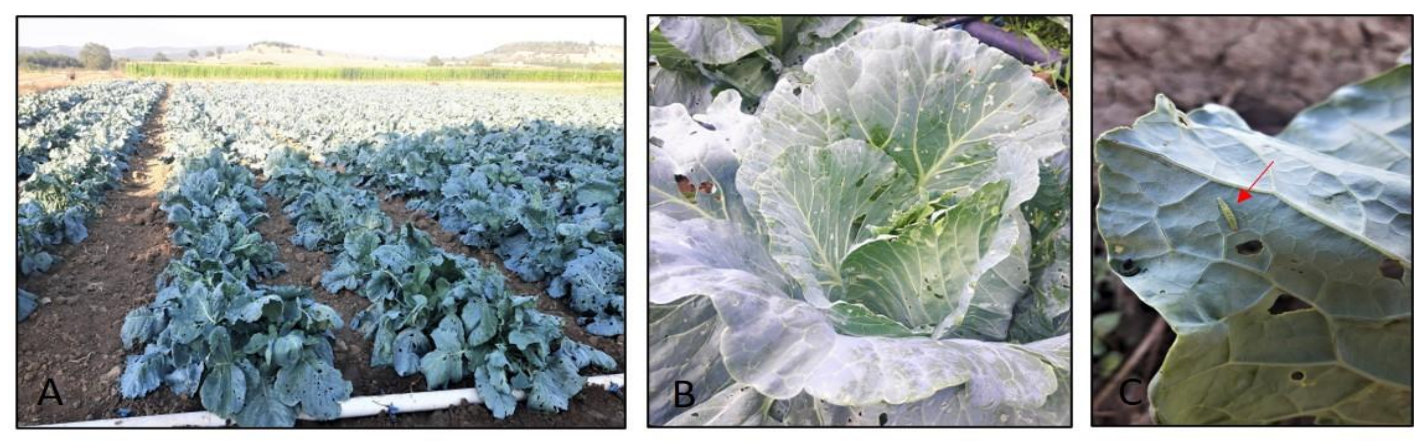

Figure 1. Field damages of diamondback moth (A, B) and a larva on cabbage (C) 

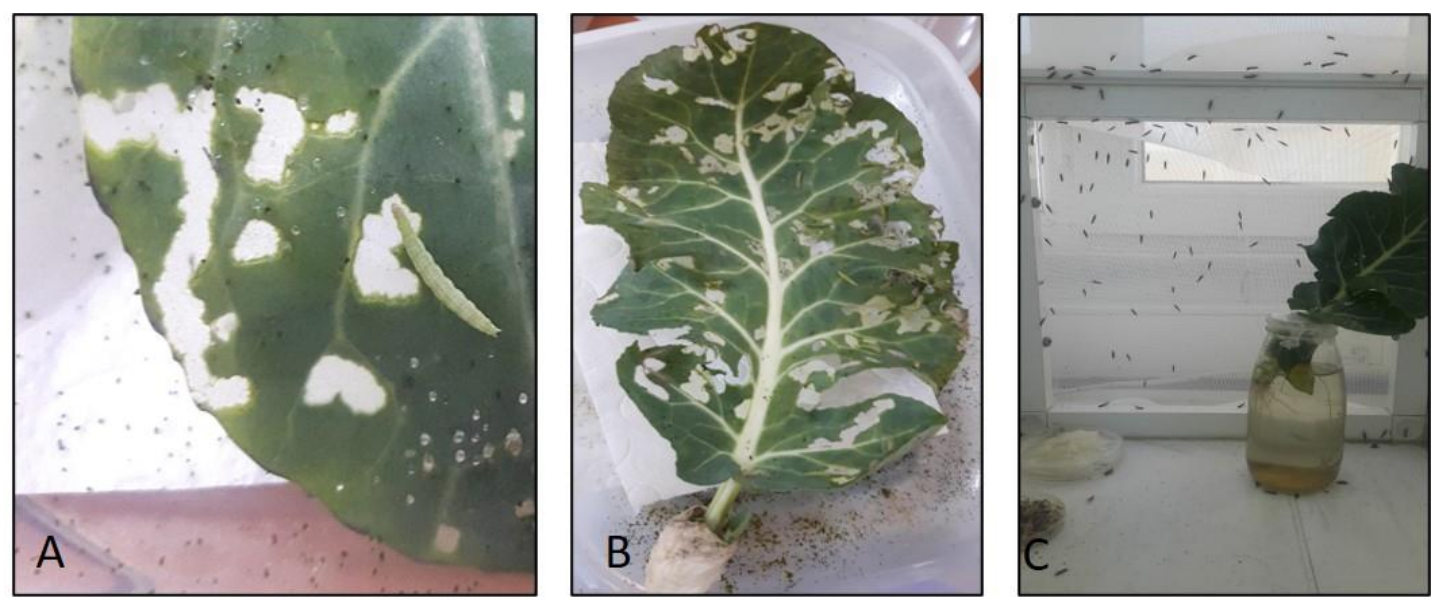

Figure 2. Laboratory rearing of the immature stages of diamondback moth (A, B) and adult colony cage $(\mathrm{C})$

A total of 200 eggs was randomly selected for 10 consecutive days and placed in a petri dish having moistened black filter paper. The length and width of the eggs were measured under Olympus SZX9 stereozoom microscope. The egg developments were monitored daily until hatching and photographed with the Olympus 7.1 MegaPixel digital camera. Newly hatched larvae were used to test the larval host preferences in the laboratory experiments. Tested host leaves were wrapped with moistened cotton, placed in a $0.8 \mathrm{ml}$ plastic container with a neonate. Trials were carried out with 25 replications for each host. Fresh leaves were provided as needed.

In order to determine larval stages, the head capsule diameters of diamondback moth larvae were measured under the microscope and observed for molting or exuvia daily. The developmental times of each stages were recorded until become pupae. All biological parameters such as survivorship, measurement of width, length, weight of larvae and pupae were recorded for each tested host plant. Sex determination of mature larvae was made easily based on the spot or pale colored of dorsal view of the $8^{\text {th }}$ abdominal segment (Liu and Tabashnik, 1997). Adults ( + : $\left.\delta^{-}\right)$were allowed to mate in small adult cages $(15 \times 15 \mathrm{~cm})$ to determine fecundity. Additionally, pre-oviposition, oviposition and post-oviposition periods were recorded. The fecundity (the number of deposited egg), egg survival (the number of hatched egg), survival rate (the percentage of hatched egg) and egg duration periods were determined on each tested host. Their morphological features were observed and photographed. Statistical analysis of the biological parameters was performed using the SAS software, according to PROC GLM procedure, LSD (Least Significant Difference) test (version 9.1.3; SAS Institute, Cary, NC) (1990).

\section{Results and Discussion \\ Eggs}

The eggs were laid individually or small groups (2-12) on tested leaves or occasionally anywhere in the adult cages. Eggs are pale yellowish green in color, oval shaped and flattened (Figure 3) and about $0.29 \pm 0.02 \mathrm{~mm}$ in wide, $0.48 \pm 0.03 \mathrm{~mm}$ in long and $0.0057 \pm 0.00005 \mathrm{mg}$ in weight $(n=200)$. The eggs initially were creamy green in color (Figure 3A) and about 2-day old egg, the darker spots became visible on the anterior part of the eggs (Figure 3B) then darker patches became more visible when eggs were 3-day old (Figure 3C). Then, the head of neonate showed up through the chorion (Figure 3D). Eggs were deposited on tested host leaves and egg incubation times were observed in the laboratory. The mean periods of egg development were about $5.05 \pm 0.15$ days on cauliflower, $4.30 \pm 0.25$ days on broccoli and $4.9 \pm 0.31$ days on white cabbage at $20 \pm 2^{\circ} \mathrm{C}$ with $76.48 \%$, $62.66 \%$ and $74.58 \%$ viability respectively in the laboratory (Table 1 ). There was no statistically significant difference in the length, width and weight measurements of the eggs lay in different hosts. Egg hatching was also observed under microscope (Figure 4). It was reported that the embryo gradually becomes more prominent inside the egg during its development. Larval head movement and 
chewing the chorion was photographed then neonate start moving around and looking for food (Figure 4).
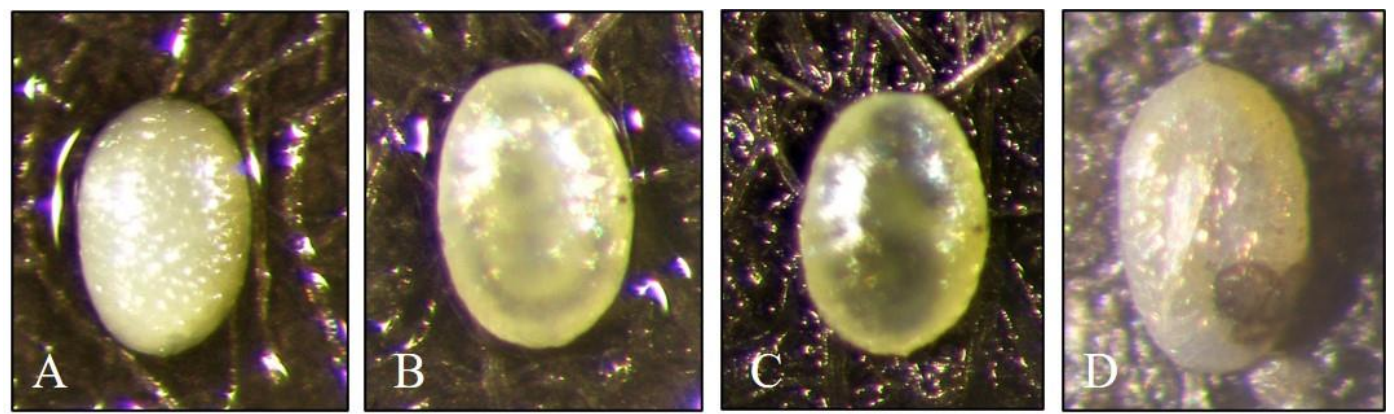

Figure 3. Egg development of Plutella xylostella, (A) 1-day old egg, (B) 2-day old egg, C) 3-day old and D) egg before hatching
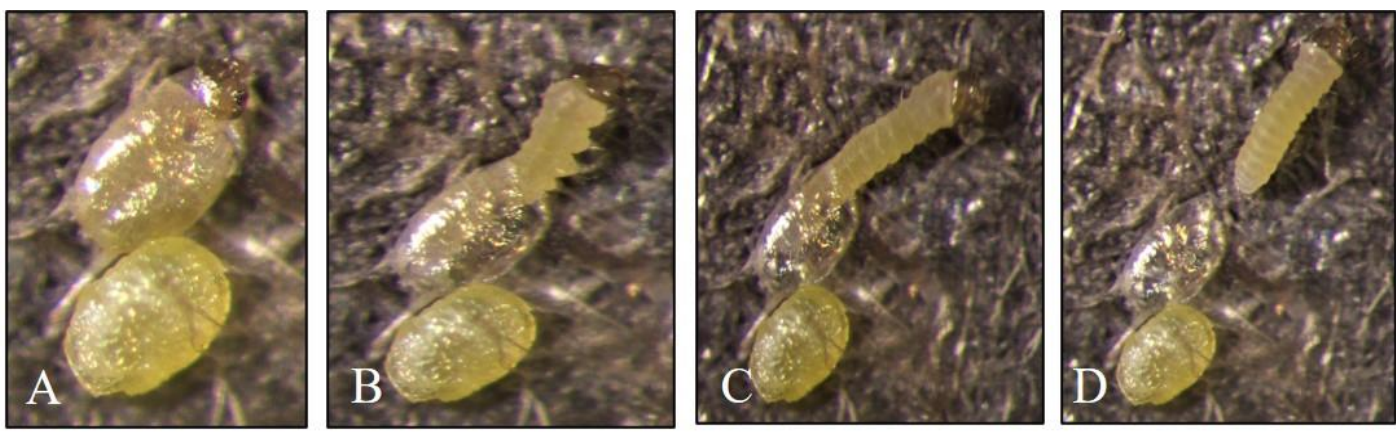

Figure 4. The progress of Plutella xylostella egg hatching (A, B, C) and a neonate (D)

\section{Larvae}

The diamondback moth larvae were reared to pupal stage on cauliflower, broccoli and white cabbage leaves in the laboratory. Larval head capsule measurements were taken on each tested host and had distinctively four instars in the laboratory. The mean head capsule widths were about 0.15 , $0.26,0.41$ and $0.58 \mathrm{~mm}$ (Table 1), but no statistical difference was found in the measurements of the head capsule widths between the tested hosts. The larvae stop feeding before molting and rested by weaving a silky web around them. After molted, they leave the skin or exuvia and head capsules (Figure 5).

Table 1. Measurements of head capsules widths of the diamondback moth on different hosts $(\mathrm{Mean} \pm \mathrm{SE}, \mathrm{N}=25)^{*}$

\begin{tabular}{cccc}
\hline $\begin{array}{c}\text { Head capsule } \\
\text { diameter }(\mathrm{mm})\end{array}$ & Cauliflower & Broccoli & White cabbage \\
\hline I. instar & $0.151 \pm 0.01 \mathrm{a}$ & $0.151 \pm 0.01 \mathrm{a}$ & $0.151 \pm 0.01 \mathrm{a}$ \\
II. instar & $0.283 \pm 0.01 \mathrm{a}$ & $0.251 \pm 007 \mathrm{bc}$ & $0.256 \pm 0.012 \mathrm{~b}$ \\
III. instar & $0.416 \pm 0.015 \mathrm{a}$ & $0.410 \pm 0.02 \mathrm{a}$ & $0.412 \pm 0.021 \mathrm{a}$ \\
IV. instar & $0.581 \pm 0.03 \mathrm{ab}$ & $0.591 \pm 0.02 \mathrm{a}$ & $0.588 \pm 0.054 \mathrm{a}$ \\
& & & \\
\hline
\end{tabular}

*The differences among instars marked by not the same letter $(\mathrm{a}, \mathrm{b})$ are significant $(\mathrm{P}<0.05$, LSD test). 


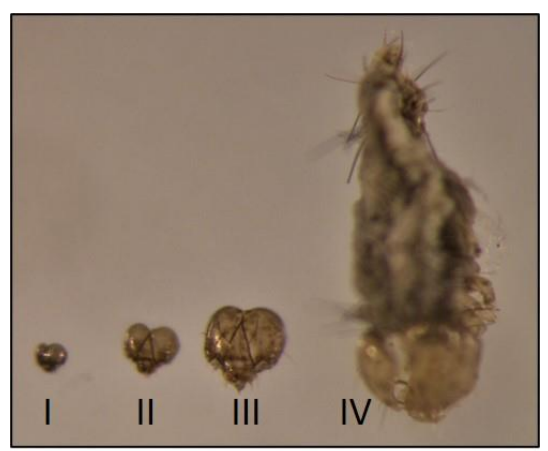
exuvia)

Figure 5. The larval head capsules of the diamondback moth (I, II, II and IV instars with

The first instar has a dark brown head and cream-colored body (Figure 6A). The pronotum has a visible brown patch and whole body is covered with short hairs. The first instars complete their development inside the mines then feed on the surfaces of the leaves. There was no significant difference in the weight of neonate larvae between the tested hosts as about $0.014 \pm 0.001 \mathrm{mg}$. The first instars were about $0.893 \pm 0.89 \mathrm{~mm}, 0.853 \pm 0.004 \mathrm{~mm}$ and $0.853 \pm 0.85$ in length and $0.161 \pm 0.003 \mathrm{~mm}$, $0.162 \pm 0.004 \mathrm{~mm}$ and $0.161 \pm 0.003 \mathrm{~mm}$ in width on cauliflower, broccoli and white cabbage, respectively. The durations of first instar were about $2.16 \pm 0.38$ days, $3.38 \pm 0.5$ days and $4.11 \pm 0.67$ days on cauliflower, broccoli and white cabbage in the laboratory (Table 2). The survival rate of first instar was $100 \%$ on the tested hosts. Larval color was changed to pale green after first instar (Figure $6 \mathrm{~B}, \mathrm{C}, \mathrm{D})$.
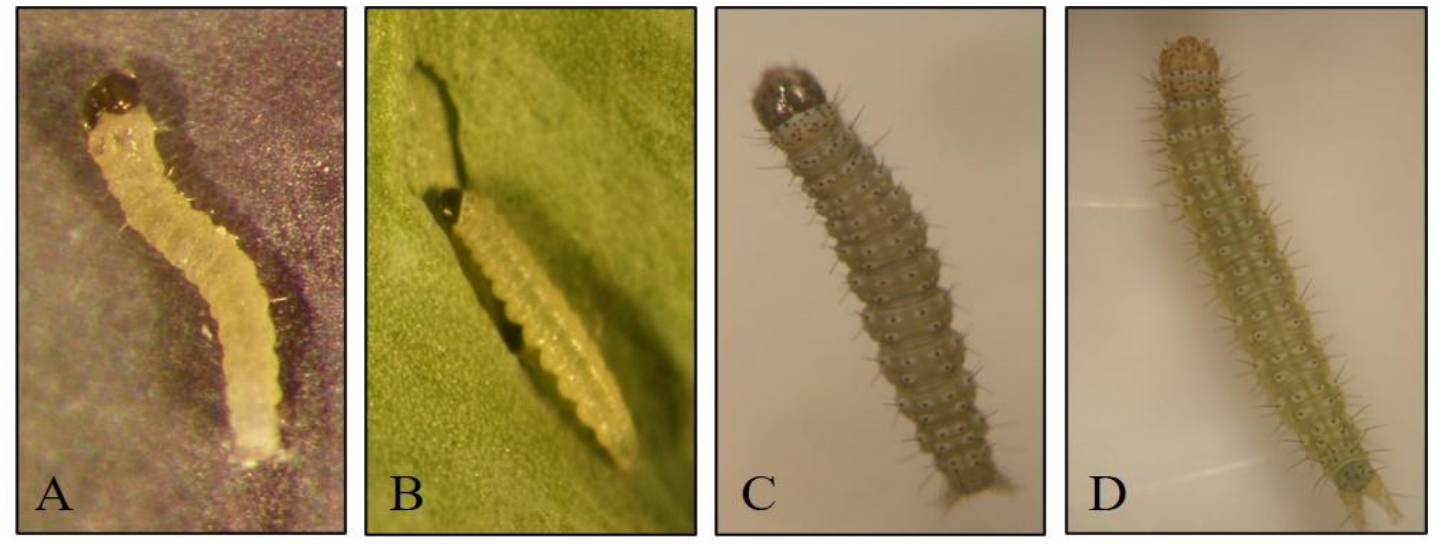

Figure 6. Different larval stages of Plutella xylostella. A) $1^{\text {st }}$ instar, B) $2^{\text {nd }}$ instar, C) $3^{\text {rd }}$ instar and D) $4^{\text {th }}$ instar

The second instar has a dark colored head with pale green body. There was a difference in the weight of second instar between the tested hosts as $0.07 \pm 0.009 \mathrm{mg}, 0.079 \pm 0.002 \mathrm{mg}$ and $0.063 \pm 0.006$ $\mathrm{mg}$ on cauliflower, broccoli and white cabbage, respectively. The second instars were about $2.00 \pm 0.160 \mathrm{~mm}, 1.61 \pm 0.10 \mathrm{~mm}$ and $1.76 \pm 0.210 \mathrm{~mm}$ in length and $0.364 \pm 0.040 \mathrm{~mm}, 0.33 \pm 0.041 \mathrm{~mm}$ and $0.28 \pm 0.041 \mathrm{~mm}$ in width on cauliflower, broccoli and white cabbage, respectively. The duration of second instar were about $3.16 \pm 0.38$ days, $3.05 \pm 0.53$ days and $2.55 \pm 0.70$ days on cauliflower, broccoli and white cabbage in the laboratory (Table 2, Figure 6B). The survival rates of second instar were $96 \%, 88 \%, 96 \%$ on cauliflower, broccoli and white cabbage, respectively.

The third instar has visible small white patches with the presence of $\mathrm{V}$ shaped anal legs. There was a difference in the weight of third instar between the tested hosts as $0.435 \pm 0.129 \mathrm{mg}, 0.554 \pm 0.110$ $\mathrm{mg}$ and $0.410 \pm 0.131 \mathrm{mg}$ on cauliflower, broccoli and white cabbage, respectively. The third instars were about $3.61 \pm 0.38 \mathrm{~mm}, 3.06 \pm 0.30 \mathrm{~mm}$ and $3.06 \pm 0.35 \mathrm{~mm}$ in length and $0.551 \pm 0.066 \mathrm{~mm}$, $0.546 \pm 0.068 \mathrm{~mm}$ and $0.528 \pm 0.04 \mathrm{~mm}$ in width on cauliflower, broccoli and white cabbage, respectively. The durations of third instar were about $2.94 \pm 0.41$ days, $3.22 \pm 0.42$ days and $2.94 \pm 0.53$ 
days (Table 2, Figure 6C). The survival rates of third instar were $95.8 \%, 100 \%, 91.6 \%$ on cauliflower, broccoli and white cabbage, respectively.

The fourth instar has a similar appearance to third instar. There was a significant difference in the weight of fourth instar between the tested hosts as $1.81 \pm 0.29 \mathrm{mg}, 2.64 \pm 0.76 \mathrm{mg}$ and $2.00 \pm 0.45 \mathrm{mg}$, on cauliflower, broccoli and white cabbage, respectively. The fourth instars were about $6.17 \pm 0.36$ $\mathrm{mm}, 5.68 \pm 0.62 \mathrm{~mm}$ and $4.96 \pm 0.66 \mathrm{~mm}$ in length and $0.795 \pm 0.05 \mathrm{~mm}, 0.94 \pm 0.11 \mathrm{~mm}$ and $0.871 \pm 0.06$ $\mathrm{mm}$ in width on cauliflower, broccoli and white cabbage, respectively. The durations of fourth instar were about $3.61 \pm 0.5$ days, $3.05 \pm 1.05$ days and $4.11 \pm 0.67$ days on cauliflower, broccoli and white cabbage, respectively (Table 2, Figure 6D). The survival rate of fourth instar was $100 \%$ on the tested hosts.

It was easy to differentiate male and female individuals when they became mature larvae by having a yellow patch on dorsal part of the $8^{\text {th }}$ abdominal segment which was a male, if there was no stain, which was a female (Figure 7A). Sex differentiation in mature larvae is crucial for the laboratory studies. Because the diamondback moth has a loose silk cocoon during pupal stage which should be removed to see pupal sex characters that is time consuming and may damage the pupae.
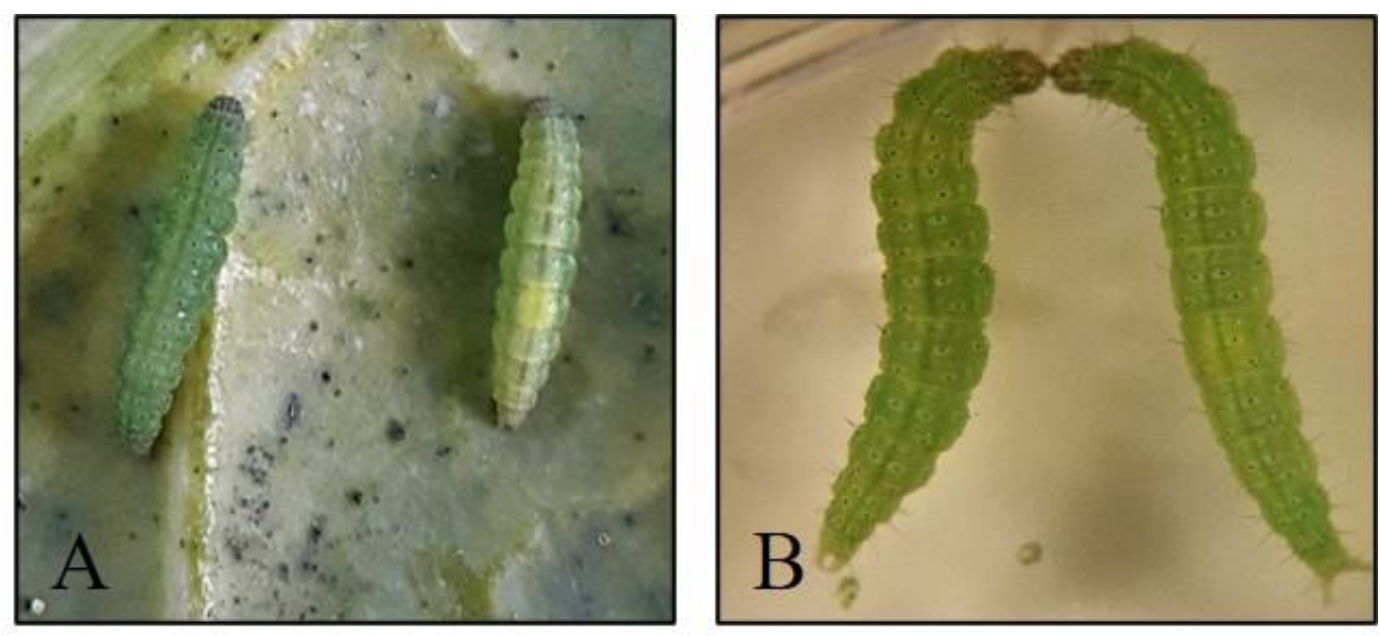

Figure 7. The fourth instars (mature larvae) (A, B). Female on the left and male on the right.

\section{Pre-Pupae and Pupae}

When larva was fully grown, and it starts forming a loose silk cocoon on the leaves (Figure 8). Mature larva was visible through silky web at the beginning (Figure 8A) then became prepupa with leaving the last exuvia (Figure 8B). The pupa was initially soft and yellowish green then turned to brown in color (Figure 8C). The measurements of female pupae were about $1.48 \pm 0.09 \mathrm{~mm}, 1.52 \pm 0.07$ $\mathrm{mm}$ and $1.48 \pm 0.05 \mathrm{~mm}$ in wide, $6.38 \pm 0.14 \mathrm{~mm}, 6.47 \pm 0.19 \mathrm{~mm}$ and $6.19 \pm 0.34 \mathrm{~mm}$ in long, and weighed as $8.08 \pm 0.83 \mathrm{mg}, 8.25 \pm 0.61 \mathrm{mg}$ and $7.33 \pm 1.17 \mathrm{mg}$ on cauliflower, broccoli and white cabbage, respectively. Male pupae were about $1.42 \pm 0.07 \mathrm{~mm}, 1.43 \pm 0.04 \mathrm{~mm}$ and $1.34 \pm 0.03 \mathrm{~mm}$ in wide and $6.08 \pm 0.14 \mathrm{~mm}, 6.07 \pm 0.14 \mathrm{~mm}$ and $5.63 \pm 0.25 \mathrm{~mm}$ in long, and weighed as $6.53 \pm 0.30 \mathrm{mg}$, $6.96 \pm 0.51 \mathrm{mg}$ and $5.24 \pm 0.46 \mathrm{mg}$ on cauliflower, broccoli and white cabbage, respectively.

The durations of female pre-pupa were about $1.12 \pm 0.35$ days, $1.37 \pm 0.51$ days and $1.12 \pm 0.35$ days and male pre-pupa were about $1.33 \pm 0.50$ days, $1.77 \pm 0.44$ days and $1.11 \pm 0.33$ days on cauliflower, broccoli and white cabbage, respectively. The durations of female pupal stadium were about $5.37 \pm 0.51$ days, $6.75 \pm 0.70$ days and $6.62 \pm 0.74$ days and as $6.66 \pm 0.50$ days, $7.55 \pm 0.72$ days and $8.22 \pm 0.66$ days in male pupae on cauliflower, broccoli and white cabbage, respectively. The pre-pupal and pupal emergences were $100 \%$ on cauliflower, $100 \%$ and $95.45 \%$ on broccoli, $95.45 \%$ and $95.23 \%$ on white cabbage, respectively. 

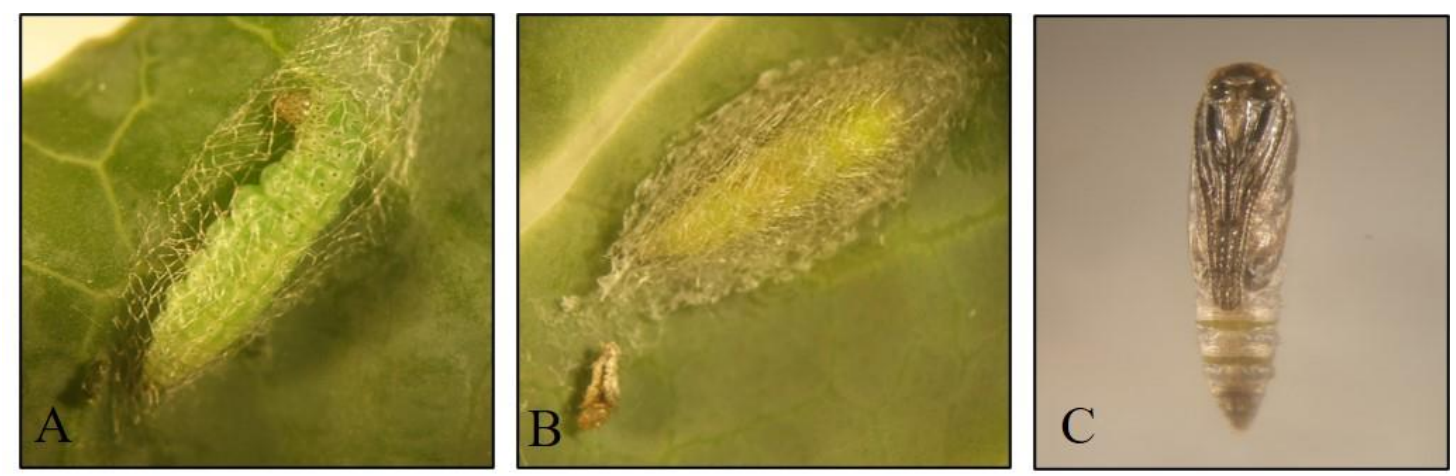

Figure 8. Mature larva (A), prepupa (B) and pupal stages (C) of the diamondback moth

\section{Adult}

Adults of diamondback moth are brown or grayish in color with prominent antennae and having with a broad cream band. Sometimes, the band is formed light-colored diamonds on the back which is the characteristic view of the moth (Figure 9). The female wingspans were about $13.6 \pm 0.54$ $\mathrm{mm}, 12.6 \pm 0.54 \mathrm{~mm}$ and $11.8 \pm 0.83 \mathrm{~mm}$ and male wingspans were about $1.6 \pm 0.54 \mathrm{~mm}, 12.8 \pm 0.44 \mathrm{~mm}$ and $11.4 \pm 0.54 \mathrm{~mm}$ when larvae were reared on cauliflower, broccoli and white cabbage, respectively. The pre-oviposition times of the females were $4.87 \pm 8.00$ days on broccoli, $1.62 \pm 0.74$ days on cauliflower and $4.12 \pm 4.35$ days on white cabbage. The longest oviposition period was $10.12 \pm 5.24$ days for cauliflower leaves, while the shortest on broccoli leaves as $6.75 \pm 5.06$ days.

The oviposition period was observed as $4.12 \pm 4.35$ days on white cabbage. The longevities of females were recorded as $20.87 \pm 12.25$ days, $14.00 \pm 6.43$ days and $17.87 \pm 5.79$ days and the longevities of males were $29.12 \pm 8.90$ days, $24.62 \pm 7.15$ days and $16.12 \pm 8.27$ days cauliflower, broccoli and white cabbage, respectively (Table 2). A female laid about $251.50 \pm 81.37$ eggs on cauliflower, $210.62 \pm 138.09$ eggs on broccoli and $120.00 \pm 93.33$ eggs on white cabbage leaves in her life span.

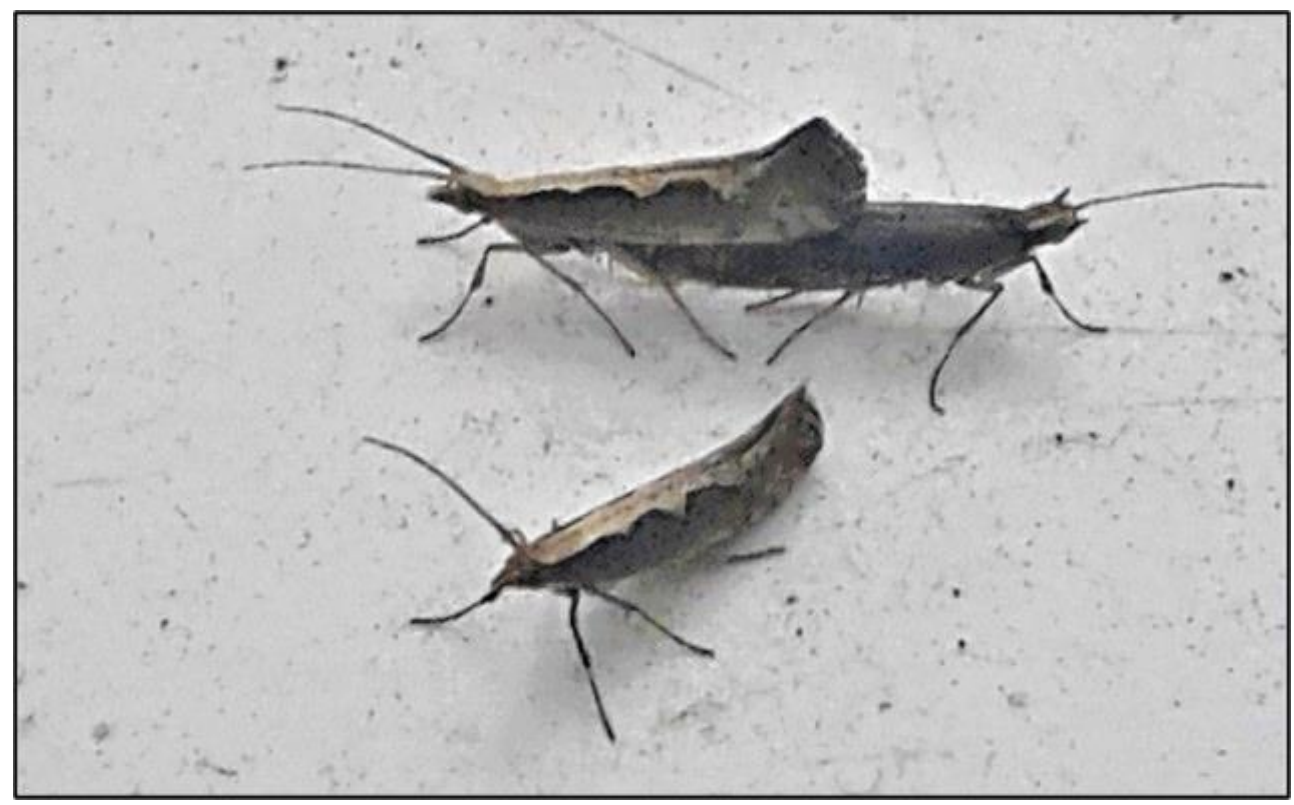

Figure 9. Adult stages of the diamondback moth 
Table 2. The durations of biological stages and fitness parameters of the diamondback moth (days, Mean \pm SD)

Parameters of biological stages

(days) Cauliflower Broccoli $\quad$ White cabbage

\begin{tabular}{llll}
\hline Egg Duration & $5.05 \pm 0.15 \mathrm{a}$ & $4.3 \pm 0.25 \mathrm{~b}$ & $4.9 \pm 0.31 \mathrm{a}$ \\
First Instar & $2.16 \pm 0.38 \mathrm{c}$ & $3.38 \pm 0.5 \mathrm{~b}$ & $4.11 \pm 0.67 \mathrm{a}$ \\
Second Instar & $3.16 \pm 0.38 \mathrm{a}$ & $3.05 \pm 0.53 \mathrm{a}$ & $2.55 \pm 0.7 \mathrm{~b}$ \\
Third Instar & $2.94 \pm 0.41 \mathrm{ab}$ & $3.22 \pm 0.42 \mathrm{a}$ & $2.94 \pm 0.53 \mathrm{ab}$ \\
Fourth Instar & $3.61 \pm 0.5 \mathrm{ab}$ & $3.05 \pm 1.05 \mathrm{~b}$ & $4.11 \pm 0.67 \mathrm{a}$ \\
Male Pre-Pupal duration & $1.33 \pm 0.5 \mathrm{~b}$ & $1.77 \pm 0.44 \mathrm{a}$ & $1.11 \pm 0.33 \mathrm{~b}$ \\
Female Pre-Pupal duration & $1.12 \pm 0.35 \mathrm{a}$ & $1.37 \pm 0.51 \mathrm{a}$ & $1.12 \pm 0.35 \mathrm{a}$ \\
Male Pupal duration & $6.66 \pm 0.5 \mathrm{c}$ & $7.55 \pm 0.72 \mathrm{~b}$ & $8.22 \pm 0.66 \mathrm{a}$ \\
Female Pupal duration & $5.37 \pm 0.51 \mathrm{~b}$ & $6.75 \pm 0.7 \mathrm{a}$ & $6.62 \pm 0.74 \mathrm{a}$ \\
Male adult longevity & $29.12 \pm 8.9 \mathrm{a}$ & $24.62 \pm 7.15 \mathrm{ab}$ & $16.12 \pm 8.27 \mathrm{bc}$ \\
Female adult longevity & $20.87 \pm 12.2 \mathrm{a}$ & $14.00 \pm 6.4 \mathrm{ab}$ & $17.87 \pm 5.8 \mathrm{a}$ \\
Pre-oviposition & $1.62 \pm 0.74 \mathrm{ab}$ & $4.87 \pm 8.00 \mathrm{a}$ & $4.12 \pm 4.35 \mathrm{a}$ \\
Oviposition & $10.12 \pm 5.24 \mathrm{a}$ & $6.75 \pm 5.06 \mathrm{a}$ & $9.50 \pm 6.84 \mathrm{a}$ \\
Post-oviposition & $9.12 \pm 10.66 \mathrm{a}$ & $2.25 \pm 2.76 \mathrm{bc}$ & $4.25 \pm 3.99 \mathrm{bc}$ \\
Fecundity (number) & $251.5 \pm 81.4 \mathrm{a}$ & $210.6 \pm 138.1 \mathrm{ab}$ & $120.0 \pm 93.3 \mathrm{bc}$
\end{tabular}

* Within rows, the differences between the averages of treatments marked by not the same letter $(\mathrm{a}, \mathrm{b}, \mathrm{c})$ are significant $(\mathrm{P}<$ 0.05 , LSD test).

This study reports that diamondback moth was successfully reared on cauliflower, broccoli and white cabbage leaves in the laboratory. We determined the diamondback moth larvae had 4 instars based on molts and head capsule measurements on tested host leaves. Many reports have shown some variations in head capsule diameter of diamondback moth larvae but the number of larval stages was four (Jaleel et al., 2019; Alizadeh et al., 2011). Host plant components (carbon, nitrogen, plant defense metabolites etc.) show variations in insect behavior such as feeding and oviposition (Syed and Abro, 2003). The high reproductive potential and shorter development period of an insect in a specific host plant indicates that the plant is suitable for the insect (Awmack and Leather, 2002). Host preference and feeding suitability for pest insects varies regarding survival rates, number of instars and continuous reproduction (Saeed et al., 2010; Talekar and Shelton, 1993). Nutrition levels of host plants especially protein contents are important and also effect the durations of biological stages, growth and fecundity in the laboratory (Mostafa et al., 2011; Renwick and Radke, 1990). This study showed that the diamondback moth larvae grow faster and complete their development faster with the highest fecundity on cauliflower than broccoli and white cabbage. Cauliflowers promote faster larval development and higher fecundity compared to Napa and white cabbage (Jaleel et al., 2019; Golizadeh et al., 2007). Successful laboratory maintenance and population rate of the diamondback moth initially were dependent on fecundity, larval survival and development (Saeed et al., 2019). Renwick and Radke (1990) reported that host plants have diverse effects on oviposition and fecundity in females of P. xylostella. Singh and Singh (1982) and Golizadeh et al. (2009) studied the incidence of different Brassicaeous plants on the survival and development of diamondback moth. They reported also the shortest development time and the highest survival rate in cauliflower leaves then canola, kohlrabi and white cabbage varieties. In this study, the durations of the immature stages and survivorship were the highest on cauliflower with the longest oviposition times and fecundity which indicates cauliflower as the preferred host.

\section{Conclusion}

In this study, we investigated the life cycle of P. xylostella on cauliflower, broccoli and white cabbage under favorable laboratory conditions. All biological stages were reported here to help the pest's surveys in Brassicae fields. Laboratory reared adults were mated and deposited eggs on tested hosts for continues generations. Additionally, the present study reported that cauliflower is a suitable 
larval host for the diamondback moth to rear in the laboratory so it may also help to survey the pest preferably in cauliflower fields. Further research is needed regarding to the mass rearing of the diamondback moth for pest management and screening genetic diversity to understand the origin of the diamondback moth population in Turkey.

Acknowledgment: This research study is a part of the master thesis of first author. This study was supported partially by Çanakkale Onsekiz Mart University, Scientific Research Council (Grant number: FYL-2020-3351).

\section{References}

Alizadeh, M., Rassoulian, G. R., Karimzadeh, J., Hosseini- Naveh V., Farazmand, H. 2011. Biological Study of Plutella xylostella (L.) (Lepidoptera: Plutellidae) and it's Solitary Endoparasitoid, Cotesia vestalis (haliday) (Hymenoptera: Braconidae) under Laboratory Conditions. Pakistan Journal of Biological Sciences. 14: 1090-1099.

Alkan, B., 1965. Murgul Bölgesi karalahanalarda görülen lahana güvesi Plutella maculipennis Curt. (Lep: Plutellidae)'nin biyolojisi üzerinde bazı incelemeler ve mücadele usulleri. A.Ü.Zir.Fak.Y1ll. 15(1):7491.

Atay E., Efil L., Tatlı M., Alaca B., 2019. The first record for Plutella xylostella (Linnaeus, 1758) (Lepidoptera: Plutellidae) in Çanakkale parodince of Turkey and external and genital morphology of the species. Eurasian Journal of Biological and Chemical Sciences. 2(1):7-10.

Awmack, C.S., Leather, S.R., 2002. Host plant quality and fecundity in herbivorous insects. Annu. Rev. Entomol. 47:817-844.

Avc1, Ü., H.Özbek, 1990. Erzurum'da lahana zararlısı lepidopter türleri ve parazitoidleri üzerinde bir araştırma. Türkiye II. Biyolojik Mücadele Kongresi Bildirileri. 26-29 Eylül, 1990. Entomoloji Derneği Yayınları No: 319-329.

Colinet H., Sinclair B.J., Vernon P., Renault D. 2015. Renault Insects in fluctuating thermal environments. Annual Review of Entomology. 60: 123-140.

De Bortoli SA, Planczyk RA., Vacari AM., De Bortoli CP., Duarte RT. 2014. Plutella xylostella (Linnaeus, 1758) (Lepidoptera, Plutellidae): Tactics for intigrated pest management in Brassicaceae. Intech, 31-51.

French, B.A., White J.H. 1960. The diamondback moth outbreak of 1958. Plant Path., 9:77-84

Golizadeh A., Kamalı K., Fathipour Y., Abbasipour H. 2007. Temperature-dependent development of diamondback moth, Plutella xylostella (Lepidoptera: Plutellidae) on two brassicaceous host plants. Insect Science. 14(4):309-316.

Golizadeh, A., Kamali, K., Fathipour, Y., Abbasipour, H. 2009. Effect of temperature on life table parameters of Plutella xylostella (Lepidoptera: Plutellidae) on two brassicaceous host plants. Journal of Asia-Pacific Entomology. 12(4):207-212.

Jaleel W., Saeed, S., Saeed, Q., Naqqash, M.N., Sial, M.U., Aıne, Q.U., Yanyuan, L., Ru1, Z., He, Y., Lu, L. 2019. Effects of three different cultivars of cruciferous plants on the age-stage, two-sex life table traits of Plutella xylostella (L.) (Lepidoptera: Plutellidae). Entomological Research. 49:151-157.

Kfir R. 1998. Origin of the Diamondback Moth (Lepidoptera: Plutellidae). Annals of the Entomological Society of America. 91(2):164-167.

Liu, Y. B., Tabashnik, B. E. 1997. Visual determination of sex of diamondback moth larvae. Canadian Entomologist. 129(3): 585-586.

Magaro J. J., Edelson J. V. 1990. Diamondback Moth (Lepidoptera: Plutellidae) in South Texas: A Technique for Resistance Monitoring in the Field. Journal of Economic Entomology. 83(4): 1201-1206.

Mohan, M., Gujar, G. T. 2003. Local variation in susceptibility of the diamondback moth, Plutella xylostella (Linneaus) to insecticides and detoxification enzymes. Crop Protection. 22: 495-05.

Mostafa, A.M., Lowery, D.T., Jensen, L.B.M., Deglow, E.K. 2011. Host suitability and feeding Preferences of the Grapevine Pest Abagrotis orbis (Lepidoptera:Noctuidae) Environmental Entomology. 40(6): 1458146.

Renwick J.A.A., Radke C.D. 1990. Plant constituents mediating oviposition by the diamondback moth, Plutella xylostella (L.) (Lepidoptera: Plutellidae). Phytophaga. 3(1):37-46.

Saeed, R., Sayyed A.H., Shad S.A., Zaka S.M. 2010. Effect of different host plants on the fitness of diamondback moth, Plutella xylostella (Lepidoptera: Plutellidae). Crop Protection. 29:178-182.

Saeed S., Jaleel W., Naqqash M.N., Saeed Q., Zaka S.M., Sarwar Z.M., Ishtiaq M., Qayyum M.A., Sial M.U., Batool M. 2019. Fitness parameters of Plutella xylostella (L.) (Lepidoptera; Plutellidae) at four constant temperatures by using age-stage, two-sex life tables. Saudi J. Biol. Sci., 26 (7): 1661-1667.

SAS. 1990. SAS/STATuser'sversion 6, 4thedition. Vol. 1 \& 2. Cary: SAS Institute Inc.

Singh, S.P., Singh, D., 1982. Influence of cruciferous host plants on the survival and development of Plutella xylostella. Journal of Research Punjab Agricultural University 19: 100-104. 
Syed T.S., Abro G.H. 2003. Effect of Brassica Vegetable Hosts on Biology and Life Table Parameters of Plutella xylostella Under Laboratory Conditions. Pakistan Journal of Biological Sciences. 6(22):18911896.

Tabashnik B.E., Cushing N.L., Finson N., Johnson M.W. 1990. Field Development of Resistance to Bacillus thuringiensis in Diamondback Moth (Lepidoptera: Plutellidae). Journal of Economic Entomology. 83(5): 1671-1676.

Talekar, N.S., H.C. Kong, S.T. Lee, B.S. Chlen, Sun, L.Y., 1985. Annolated bibliography of the diamondback moth. Asian Vegetable Research and Development Center, Taiwan, 469.

Talekar, N.S., A.M. Shelton, 1993. Biology, ecology and management of the Diamondback moth. Annual Review of Entomology. 38: 275-301.

Zalucki M. P., Shabbir A., Silva R., Adamson D., Su-Sheng L., Furlong M. J., 2012. Estimating the Economic Cost of One of the World's Major Insect Pests, Plutella xylostella (Lepidoptera: Plutellidae): Just How Long Is a Piece of String? Journal of Economic Entomology. 105(4):1115-1129. 